Original Paper

\title{
Training of Trainer (TOT) Dukungan Psikologis dan Self Empowerment Paska Bencana Bagi Staf dan Mahasiswa Fakultas Kedokteran Universitas Mataram
}

\author{
Emmy Amalia ${ }^{1 *}$, Ima Arum L. ${ }^{1}$, Sigit Kusdaryono ${ }^{1}$ \\ ${ }^{1}$ Fakultas Kedokteran, Universitas Mataram
}

*Corresponding Author: Emmy Amalia, Fakultas Kedokteran, Universitas Mataram, Indonesia; Email: emmy.amalia@ymail.com

\begin{abstract}
Bencana adalah peristiwa atau rangkaian peristiwa yang mengancam dan mengganggu kehidupan dan penghidupan masyarakat yang disebabkan, baik oleh faktor alam dan/atau non-alam maupun faktor manusia sehingga mengakibatkan timbulnya korban jiwa manusia, kerusakan lingkungan, kerugian harta benda, serta dampak psikologis. Beberapa dampak psikologis yang sering muncul meliputi perubahan emosional akibat pengalaman traumatis, kekhawatiran akan kelangsungan hidup dan masa depan, dan kecemasan terkait keutuhan keluarga dan lingkungan sosial. Hingga bulan Agustus 2018, tercatat telah terjadi 395 kali gempa yang melanda Provinsi NTB, dengan beberapa gempa besar dengan pusat yang berbeda-beda. Gempa bumi yang melanda provinsi NTB sejak 29 Juli 2018 ini telah menelan banyak korban jiwa dan menimbulkan banyak kerusakan, sehingga tentu saja menimbulkan ketidakseimbangan kondisi psikologis masyarakat. Fakultas Kedokteran Universitas Mataram sebagai pusat pendidikan ingin berperan serta mengatasi dampak psikologis ini dengan mengadakan Training of Trainer (ToT) dukungan psikologis dan self empowerment paska gempa bagi staf dan mahasiswa kedokteran. Dengan konsep ToT, staf dan mahasiswa kedokteran tidak hanya diajarkan untuk mampu melakukan dukungan psikologis untuk dirinya sendiri, tetapi mampu mengajarkan ke orang lain di lingkungannya maupun kepada penyintas lain saat mereka ditugaskan di lokasi bencana.
\end{abstract}

Kata kunci: Training of Trainer (TOT); Dukungan Psikologis; Self Empowerment

\section{Pendahuluan}

Bencana adalah peristiwa atau rangkaian peristiwa yang mengancam dan mengganggu kehidupan dan penghidupan masyarakat yang disebabkan, baik oleh faktor alam dan/atau non-alam maupun faktor manusia sehingga mengakibatkan timbulnya korban jiwa manusia, kerusakan lingkungan, kerugian harta benda, serta dampak psikologis. Beberapa dampak psikologis yang sering muncul meliputi perubahan emosional akibat pengalaman traumatis, kekhawatiran akan kelangsungan hidup dan masa depan, dan kecemasan terkait keutuhan keluarga dan lingkungan sosial (Undang-undang no. 24 tahun 2007). Secara garis besar, jenis bencana dapat dibagi menjadi:

1. Bencana alam, adalah bencana yang diakibatkan oleh peristiwa alam, misalnya gempa bumi dan letusan gunung berapi.
2. Bencana non-alam, adalah bencana yang diakibatkan oleh peristiwa lain diluar peristiwa alam, misalnya berupa kegagalan teknologi, kegagalan modernisasi, epidemi, dan wabah penyakit.

3. Bencana sosial, adalah bencana yang terjadi akibat kelalaian manusia yang meliputi konflik sosial, dan terror.

Sejak 29 Juli 2018 hingga saat ini, Provinsi NTB telah mengalami bencana alam berupa gempa bumi. Walaupun pusat gempa berbeda-beda, gempa dirasakan hampir di seluruh wilayah NTB, termasuk di Kota Mataram. Data dari Kepala Pusat Data dan BNPB Sutopo PurwoNugroho tercatat 395 gempa susulan telah terjadi hingga tanggal 26-8-2018. Dari 395 gempa kali gempa susulan terdapat 20 gempa besar yang dirasakan masyarakat NTB, terutama di Pulau Lombok. Menurut Pusat Krisis Kesehatan Kementrian Kesehatan Republik Indonesia, akibat 
serangkaian gempa ini terdapat 559 orang meninggal dunia, 2.257 orang mengalami luka berat (menjalani rawat inap), 36.662 orang mengalami luka ringan (menjalani rawat jalan), dan 373.329 orang menjadi pengungsi. Diantara korban terdapat pula kelompok rentan meliputi 59.603 ibu hamil, 72.582 bayi, 213.724 balita, dan 31.724 orang lanjut usia. Hal ini tentu saja menimbulkan dampak psikologis yang tidak sedikit bagi penyintas yang masih bertahan saat ini.

Secara garis besar, dampak psikologis yang sering muncul pada penyintas bencana meliputi perubahan emosional akibat pengalaman traumatis, kekhawatiran akan kelangsungan hidup dan masa depan, dan kecemasan terkait keutuhan keluarga dan lingkungan sosial. Akibatnya dapat muncul tanda dan gejala-gejala psikologis sebagai berikut:

1. Gangguan psikologis ringan, berupa kecemasan, kepanikan, ketegangan, dan lain-lain. Pemulihan normal akan terjadi dalam beberapa hari /minggu, dan umumnya intervensi spesifik seperti pengobatan tidak diperlukan. Gejala ini banyak diamati pada sebagian besar penyintas.

2. Gangguan psikologis sedang. Gejala berupa kecemasan menyeluruh, penarikan diri, hingga gangguan emosi yang menetap. Pada kondisi ini pemulihan normal akan terjadi dalam jangka waktu yang lebih panjang (dibanding gangguan ringan). Jika tidak segera diatasi, gangguan ini juga dapat mengarah ke gangguan perilaku yang lebih berat. Dukungan psikososial sangat diperlukan untuk pemulihan normal.

3. Gangguan mental dan perilaku berat, berupa gangguan mental terkait dengan trauma dan stress yang memenuhi kriteria diagnostik, misalnya post traumatic stress disorder (PTSD), gangguan depresi, kecemasan menyeluruh, fobia, ataupun gangguan disositatif. Pada tahap ini telah terjadi dampak merugikan yang luas, misalnya karena tidak mampu bekerja / sekolah, penyintas menjadi tidak berfungsi dan menjadi beban keluarganya. Pada tahap ini perlu penanganan kesehatan mental yang khusus oleh tenaga professional (psikiater).

Bagaimanapun, sebagian besar dampak psikologis yang muncul paska bencana adalah berupa reaksi stres yang normal. Apalagi jika dukungan psikologis yang tepat kepada penyintas segera diberikan. Angka kejadian gangguan psikologis yang lebih berat umumnya tidak lebih dari $10 \%$. Oleh karenanya penting untuk diberikan dukungan psikologis sejak dini yang dikenal dengan dukungan psikologis awal (psychological first aid/PFA) kepada para penyintas.

Yang dimaksud dengan dukungan psikologis awal (psychological first aid/PFA) adalah bantuan psikologis dasar bagi penyintas yang diberikan oleh masyarakat awam dan bukan profesional kesehatan mental (Allen, et al.,, 2010). Meliputi serangkaian keterampilan yang bertujuan untuk mengurangi distress dan mencegah munculnya perilaku kesehatan mental yang negatif yang disebabkan oleh bencana yang dihadapi penyintas (Everly, et al., 2006). PFA berupa perawatan dasar yang bersifat non intrusive (mendengar namun tidak memaksakan untuk berbicara) dan mendorong pendampingan tanpa paksaan dari orang-orang signifikan yang berada di sekitar penyintas (Sphere, 2004)).

Tujuan diberikannya dukungan psikologis awal adalah untuk mengembalikan fungsi penyintas pada kondisi semula, seperti sebelum situasi bencana terjadi. Adapun kerangka kerja dukungan psikologis awal pada dasarnya adalah memenuhi rasa aman bagi orang yang membutuhkan dukungan (AMAN), mendorong keberfungsian yang optimal orang yang memerlukan dukungan (FUNGSI), dan memfasilitasi tindakan orang yang memerlukan dukungan untuk pemulihannya (AKSI). Fakultas Kedokteran Universitas Mataram sebagai pusat pendidikan ingin berperan serta mengatasi dampak psikologis ini dengan mengadakan Training of Trainer (ToT) dukungan psikologis dan self empowerment paska bencana bagi staf dan mahasiswa kedokteran. Dengan konsep ToT, staf dan mahasiswa kedokteran tidak hanya diajarkan untuk mampu melakukan dukungan psikologis untuk dirinya sendiri, tetapi mampu mengajarkan ke orang lain di lingkungannya maupun kepada penyintas lain saat mereka ditugaskan di lokasi bencana.

\section{Metode Pelaksanaan}

ToT dukungan psikologis dan Self Empowerment paska bencana ini dilakukan selama 2 hari. Pelaksanaan kegiatan dibagi menjadi dua kelas yaitu kelas untuk staf non medis pada hari pertama, dan kelas untuk sfat medis dan mahasiswa pada hari kedua. Materi ToT diberikan oleh psikiater, dokter spesialis lain, dan juga dibantu oleh psikolog dan tenaga ahli lain dari tim relawan di tenda darurat 
dengan target peserta tidak lebih dari 50 orang setiap kelas, agar transfer materi ToT berjalan efektif. Pada kegiatan ini, staf dan mahasiswa dipaparkan terlebih dahulu pada materi bencana dan reaksi individu akibatnya, serta materi dukungan psikologis awal (psychological first aid/PFA). Pemberian materi bersifat interaktif, disambung dengan diskusi spontan di tempat.

Kegiatan ToT dilanjutkan dengan keterampilan melakukan dukungan psikologis yang berupa berbagai teknik relaksasi dari berbagai pendekatan disiplin ilmu. Semua peserta ToT diharapkan terlibat aktif dalam praktek pelaksanaan teknik relaksasi dan mempraktekkan hingga benar di tempat, dengan bimbingan para pemateri dan relawan.

Sebelum pelaksanaan ToT, pemateri dari Fakultas Kedokteran Universitas Mataram dan relawan berdiskusi untuk menyusun materi pelatihan berupa slide Powepoint dan materi keterampilan teknik relaksasi yang akan diajarkan. Pemateri dan relawan melakukan penilaian terhadap peserta ToT di akhir acara melalui presentasi terhadap materi dan keterampilan yang telah diajarkan oleh para peserta ToT.

\section{Hasil dan Pembahasan}

Kegiatan dilakukan selama 1 hari penuh pada Hari Kamis, tanggal 23 Agustus 2018 bertempat di Fakultas Teknik Universitas Mataram, mulai pukul 8.00-15.00 WITA, setelah beberapa hari sebelumnya tim pengabdian masyarakat bersurat dan berkoordinasi terlebih dahulu dengan Dekanat Fakultas Kedokteran Universitas Mataram. Acara dihadiri oleh 42 orang staf Fakultas Kedokteran, 3 orang perwakilan relawan ACT Gempa Lombok, 48 mahasiswa kedokteran, 1 orang staf FKIP, dan 4 orang perwakilan guru SMA dan SMP di Mataram. Acara kegiatan dibagi menjadi beberapa termin, yang terdiri atas: 1) Pembukaan, 2) Acara inti dan pelatihan, 3) Penutup.

Pada pembukaan, setelah sambutan dan doa, acara dimulai dengan sharing dan berbagi pengalaman yang dialami oleh masing-masing peserta saat terjadinya bencana gempa bumi yang terjadi beberapa kali di Lombok. Pada acara ini banyak peserta mencurahkan perasaan dan pengalamannya yang mayoritas mengandung respon emosional. Banyak peserta merasa cemas, takut, sedih, bahkan sampai menangis saat menceritakan pengalamannya. Tidak jarang terdapat anggota keluarga staf Fakultas Teknik yang terdampak langsung menjadi korban, baik mengalami luka fisik, mental, maupun kerusakan harta benda. Acara ini berlangsung kurang lebih selama satu jam.

Acara selanjutnya yang merupakan acara inti, adalah pelatihan dukungan psikologis dan self empowerment bagi staf Fakultas Teknik dan keluarganya. Dukungan psikologis dan self empowerment menggunakan pendekatan cara Capacitar, yang dapat digunakan sewaktu-waktu saat merasa lelah, bingung, cemas, atau merasa tertekan. Pendekatan ini dapat dilakukan untuk diri sendiri, maupun diajarkan kepada orang-orang di sekeliling kita. Yang menjadi tantangan adalah memadukan pendekatan ini dalam kehidupan seharihari kita sampai menjadi kebiasaan dan dapat otomatis dilakukan saat kita merasa lelah, bingung, atau merasa tertekan.

Berikut adalah beberapa langkah pendekatan cara Capacitar:

1. Latihan pernafasan

Nafas adalah sumber kehidupan yang berfungsi untuk mengalirkan energi segar kedalam jaringan dan sel tubuh kita. Saat kita menghembuskan nafas, ketegangan dan toksin yang berkumpul di badan dapat terlepas keluar. Pola nafas berubah sejalan dengan perubahan perasaan, maka demikian sebaliknya, dengan mengubah cara kita bernafas, kita dapat mengubah perasaan dan kondisi fisik kita. Latihan pernafasan yang dianjurkan adalah pernafasan perut.

\section{Gerakan Tai Chi}

Empat gerakan dasar tai chi berikut berguna untuk melepaskan ketegangan dan kesakitan, menajamkan pikiran, dan menenangkan jiwa di saat susah. Gerakan ini dapat dilakukan di pagi hari, yang terdiri atas: gerakan goyang berirama, gerakan pancuran cahaya, gerakan membuka diri untuk menerima, dan gerakan terbang di udara.

3. Pegangan jari untuk mengendalikan emosi

Di setiap jari kita ada saluran atau meridian aliran energi yang berhubungan dengan organ tubuh dan emosi yang bersangkutan. Perasaan yang sangat kuat atau luar biasa bisa menyumbat atau menghambat aliran energi, yang mengakibatkan rasa sakit atau perasaan sesak di tubuh kita. Caranya, peganglah tiap jari satu persatu, dengan tangan yang 
lain selama 2-5 menit. Tarik nafas yang dalam, rasakan perasaan kuat atau perasaan yang mengganggu di dalam diri anda. Hembuskan nafasa secara perlahan dan lepaskan. Bayangkan perasaanperasaan itu mengalir keluar dari ujung jari dan masuk ke dalam bumi.

4. Teknik mengetuk, suatu teknik untuk kebebasan emosional

Mengetuk atau menekan titik akupressur yang berhubungan dengan saluran atau meridian dimana energi mengalir ini dapat membantu membuka sumbatan energi tersebut dan mendukung aliran energi yang baik di dalam tubuh, mental, dan emosi. Tarik nafas dalam-dalam, ketuklah dengan 2 jari (telunjuk dan tengah) tangan kanan dan kiri bersama-sama pada titik-titik akupresur sebanyak 79 kali di titik dimana kedua alis dimulai; titik dimana alis berakhir, di samping sudut luar mata; titik dibawah kedua bola mata, pada tulang pipi; titik dibawah hidung (lakukan dengan satu tangan saja); titik dibawah mulut, pada dagu (gunakan satu tangan saja); titik $10 \mathrm{~cm}$ dibawah kedua ketiak; titik dibawah tulang leher, pada kedua sisi tulang dada.

\section{Pemegangan}

Pemegangan yang dilakukan adalah sangat ringan, tanpa tekanan, dan jika ada orang yang tidak suka dipegang karena trauma yang dialaminya, pemegangan ini dapat dilakukan di energi yang melingkupi badannya (tanpa menyentuh badan orang itu). Pemegangan dilakukan di area kepala (satu tangan di atas dahi, tangan yang lain di bagian bawah kepala), di area ubun-ubun (kedua ibu jari bertemu dan diletakkan pada tengah ubun-ubun, ujung-ujung jari diletakkan dengan lembut di bagian atas dahi), dan di bahu (kedua tangan diletakkan secara lembut di atas kedua bahu, tempat di badan yang berhubungan dengan kecemasan dan beban dalam hidup).

6. Pijatan kepala, leher, bahu

Titik-titik pijatan berpasangan, meliputi: kurang lebih 2,5 cm dibawah tungkai bahu (bagian luar) dimana lengan bertemu dengan bagian badan; diatas bagian dalam tulang belikat, kira-kira $5 \mathrm{~cm}$ dari tulang punggung; di atas bahu di pangkal bawah leher (otot trapezius); di kedua sisi otot bagian tengah leher; di kedua lekukan yang terletak di sisi bagian bawah kepala; dan di puncak kepala atau ubun-ubun.

\section{Pain drain (pengurasan rasa nyeri)}

Letakkan telapak tangan kiri di bagian tubuh anda yang terasa tidak nyaman lalu hadapkan telapak tangan ke bawah, menjauh dari tubuh. Bayangkan semua rasa tidak nyaman ditarik/disedot oleh jari dan telapak tangan kiri dan dikembalikan ke bumi oleh jari dan telapak tangan kanan. Proses ini dapat lebih efektif jika kita dapat membayangkan bahwa jari dan telapak tangan kanan mampu memompa keluar semua ketidaknyamanan dari titik yang ada di jari dan telapak tangan kiri.

Letakkan telapak tangan kanan di bagian tubuh anda yang terasa tidak nyaman dan angkat telapak tangan kiri ke atas kepala menghadap ke atas untuk membawa masuk energi dari universal.

\section{Pal dan Gum}

Teknik Pal dan Gum terdiri dari 8 gerakan peregangan yang bertujuan untuk meredakan ketegangan, keseimbangan, dan membawa energi pada tubuh. Delapan gerakan tersebut meliputi: upholding the heavens, opening the bow, touching heaven and earth, looking behind you, swinging the truck and head, stretching backwards, stretching the legs and toes, punch with fists, dan akhirnya diakhiri dengan berteriak sekuatnya untuk melepaskan ketegangan yang terpendam. Setelahnya, kita dapat rileks sejenak dengan menarik nafas panjang dan menikmati sensasi rileks untuk beberapa saat.

Pada acara terakhir yaitu penutup, dibuka sesi tanya jawab dan diskusi terhadap pengalaman yang dialami saat melakukan pelatihan. Dalam merawat penderita, Capacitar melibatkan pembangkitan dan penguatan dari diri untuk sembuh (instinct to heal), karena cara-cara ini mudah dipelajari dan bisa dipraktekkan sendiri untuk melepas ketegangan, menenangkan emosi, dan menjaga keseimbangan dalam kehidupan sehari-hari yang sedang sulit dihadapi. Penyembuhan atau healing yang terjadi melalui pelepasan dari energi yang tersumbat dan menguatkan aliran alami dari energi ini. Dengan aliran energi yang sudah diperbaharui, seseorang akan kembali ke keadaan yang seimbang dan sejahtera.

\section{Kesimpulan}

Banyak studi telah menyimpulkan bahwa kondisi fisik dan mental jelas terdampak setelah suatu kejadian bencana. Namun setiap manusia mempunyai naluri untuk sembuh yang dapat dibangkitkan dengan cara-cara tertentu, dan yang paling mudah dan dapat dilakukan untuk 
diri sendiri dan banyak orang salah satunya adalah dengan pendekatan metode Capacitar. Dengan metode berbasis self empowerment ini, manusia dikembalikan ke dalam kondisi kesejahteraan, yaitu kembali harmoni antara energi dari pusat energi tubuh, keseimbangan emosi, dan kondisi mental yang jernih. Training of Trainer (ToT) dukungan psikologis dan self empowerment pada staf di Fakultas Kedokteran sebagai tenaga pengajar dan pendidik, adalah mengajarkan teknik-teknik sederhana yang dapat dengan mudah dipraktekkan kepada diri sendiri, mahasiswa maupun orang-orang terdekatnya, termasuk pasien-pasiennya dan tenaga kesehatan lain pada saat kondisi bencana, sehingga akan mempunyai dampak positif yang besar untuk penyembuhan kondisi mental banyak orang paska bencana gempa bumi yang terjadi di Lombok.

\section{Daftar Pustaka}

Allen, B., Brymer, M, J., Steinberg, A, M., Vernberg, E. M., Jacobs, A., Speier, A, H., Pynoos, R, S. (2010). Perceptions of psychological first aid among providers responding to Hurricanes Gustav and Ike. $J$ Trauma Stress; 23:509-13; PMID: 20623598;

http://dx.doi.org/10.1002/jts.20539

Everly, G., Phillips, S. B., Kane, D., \& Feldman, D. (2006). Introduction to and overview of group psychological first aid. Brief Treatment and Crisis Intervention, 6(2), 130-136. https://doi.org/10.1093/brieftreatment/mhj009

Sphere. (2014). Humaniterian Charter and Minimum Standards in Disaster Response. Geneva: The Sphere Project.

Undang-undang RI. No.24 tahun 2007. Penanggulangan Bencana. Jakarta 